\title{
ANALYSIS OF SOLIDARITY PENSION SYSTEM OF UKRAINE: PROBLEMS AND MAIN WAYS OF REFORMING
}

\author{
Oleksandra STAROSTA ${ }^{1}$, \\ Uzhhorod National University, Ukraine
}

\begin{abstract}
Annotation. The aim of this work is to analyze the pension system of Ukraine, determine its main problems, and define all necessary steps for further reforming of the system taking into consideration reforms which have been carried out recently. Methodology. The research is based on statistical factors, analysis of demographic rate, level of shadow economy, fiscal burden in the country. Budget index of the Pension fund of Ukraine and level of income and expenditure of pensioners been examined too. The Results of the research have shown that modern pension system requires reforming because it is characterized with a growing number of pensioners, a decrease in their material status together with annual deficit increase in the Pension fund of Ukraine, amount of tax burden and level of shadow of economy. Practical use. Since the number of pensioners is increasing and the number of payers is decreasing, the sum of accumulated income for pensions is decreasing too, which leads to the pension system crash or failure of its main function - to protect unemployable stratum of population. That is why it is necessary to carry out a further reforming to decrease the deficit, improve living standards of pensioners, implement and develop compulsory and optional insurance. Value/originality. The above mentioned ways of reforming the pension system allow to improve the functionality of the pension scheme and material status of current and future pensioners, implement accumulation component which will benefit the development of economy and the country in general.
\end{abstract}

Key words: pension payment, budget of Pension fund of Ukraine, shadow economy, living standards of pensioners, pension reform in Ukraine.

JEL Classification: E26, H55, E62

\section{Introductory paragraph}

Pension coverage is one of types of social assistance for incapacitated persons of Ukraine. It is an important sector of state's social policy, as long as pension expenses is the only source of income for many millions of people. Pension coverage has a lot of problems that are connected with stress load on budget and working people, because in our country the amount of holders of pension is increasing annually, but the amount of taxpayers is decreasing. On top of that, considerable part of holders of pension are drawing a pension that cannot supply the needs of pensioners. Object of an article is the case study of modern solidary system of pensions, analysis of actualization of reforms in the current term and suggestions of further actions.

\section{Ukrainian pension system: the present day}

Pension system's functioning mechanism is being implemented through reallocation between generations of financial resources. Participants of this system are workers and employers that are paying unified social tax, pensioners that receive pension payment with reallocation of money funds owned by the state, that allots donations in the event of money deficiency in Pension found for pension funding.
Under the existing laws structure of pension insurance system in Ukraine, it includes three levels and is formed at the expense of state's obligatory pension insurance and voluntary additional pension insurance. Three-level pension system must allocate all risks connected with negative demographic trends in society, economical fluctuations and financial market fluctuations between its three constituents. According to expert opinion, this distribution of risks suffers to do pension system more financially sound and balanced that is going to insure workers from general loss of income after retirement and that is why is really important and profitable for them. (Pishchulina, 2012).

In current conditions in Ukraine only first and third level of pension system are functioning, second is not implemented one yet. As non-state pension coverage is unessential and is not developed enough in our country, substantially, pension payments for pensioners are realized from solidary pension system. Enhancement of social standards for retirement age citizens leads to increase in pension expenses and intensification of cost loading on the first level of national pension system. There are some problems in solidary system that we are going to look at in future. 


\section{Challenging demographic situation in Ukraine}

Pension coverage system is subjected to demographic risks inside the state. Occupation level of citizens, amount of tax payers and pensioners operates upon modern day pension coverage system and the birth rate and migration can have an effect in the future.

For current demographic situation in Ukraine typical are drastic fall of birth rate, elevation of death rate, lack of population growth, tax overloading of employable population, reduction in life expectancy of men and women, nation's health deterioration, intensification of migration processes and its impact is often on demographic and social and economic readings are often divergent or even negative.

Over past two decades demographical situation in our country is shoving fixed readings of human population reduction. Origin of that have historical roots and were accumulated through the long time. For past two decades population of our country is decreasing step-by-step. In 1990 population numbered 51.8 million and as of 1 January 2015 - only 42.9 million, population decreased over 8.9 million or $20 \%$ of inhabitants. Problem of recovery rate of inhabitants and their quality is one of key indicators of each country`s development. From the date of Ukrainian independence development downfall of had begun and lasted for a decade, from 1991 to 2001, number of newborn children for women of childbearing potential over this period decreased over two times, from the number of 1844 babies per 1000 women to 1085 .

In 2014 birth rate showings increased rolled over to 1498 babies per 1000 women. Establishment of high scales of aid aborning a child and their differentiation depending on priority of new-born child state is stimulation families for having two or more children born. But, experience has proven that, monetary incentives for birth rate are inconclusive and achievements are apart from expectations (Svenchicki, Tkachenko, \& Chapko, 2010).

As of death rate in Ukraine, over the 1991 to 2014 period it fall within the standard limits 12.1-16.6 for 1 thousand residents. During the last few years general showing for 1000 residents. (STATE STATISTICS SERVICE OF UKRAINE, 2015).

Demographic situation in Ukraine is not only characterized be depopulation it has grown into demographic crisis essential features of which are adverse movements in amount and in population's health. According to statistic data's, more than quarter of men, that are going abroad at the age of 16 , are dying shy of 60 , and that fact shows real actuality of problem of untimely death in employable age. We can see huge number of death accidents because of infections and parasitic diseases (tuberculosis and AIDS), heart attacks and blood-strokes. (Kolesnikova, 2014).

All in all in this situation, natural population increase being the difference between the number of new-borne people deceased has a negative number. Average showings are signalizing about decreasing number of people, about 5.2 people per 1000 inhabitants yearly. Death rate is higher than the birth rate, on an average in Ukraine from 1991 till 2014 only 9.9 people are born for 1000 of inhabitants, but the death rate is about 15.0 people per 1 thousand of inhabitants. The analysis result shows that there is no natural population increase, $1 / 3$ times more people are dying in our country than being born (Svechnicki, Tkachenko, Chapko, 2010).

Distinctive feature of demographic situation in Ukraine are incising amount of senior citizens with the simultaneous decreasing number employable population. For pension system it means that amount of tax payers is decreasing and amount of pensioners and pension payments are growing.

Analyzing demographical processes we need to pay our attention on such problem as population greying. Age structure of Ukraine from 1990 till 2014 number of elders is increasing step by step and amount of children is decreasing. As for 1990, people under 14 reached $21.4 \%$, in $2014-15 \%$, in other words recession reached over $6.4 \%$. Number of people at the age of 65 and older had grown to 3.1: in 1990 it was about $12.1 \%$ and in $2014-15.0 \%$.

On the top of that, according to demographic greying scale Zh. Bozhe-Garnye E. Rozzeta Ukraine belongs to countries with very high level of demographical greying because number of people at the age older than 60 is makes more than 18 percent in states population structure (Svechnicki, Tkachenko, Chapko, 2010).

\section{High pension system financial expenses}

Particularity of budget system of Ukraine and governmental finances in general constitutes the fact that vast majority of expenses on social sphere and this dynamic is growing every year and that is a negative signal and it calls for measures for expansion reduction on social sphere.

Pension system of Ukraine has a very high price for society. When we talk about pension systems that are operated by the state, often we forget that pension expenses are financing by enjoyable people. But in the addition to financing social needs state makes working class to make money transfers for unemployed (Ponomarenko, 2013).

Till 2004 level of pension expenses was less than 9-10\% of GDP, after reform this reference gown up to $13-15 \%$. In 2007 pension expenses were 13.3, in $2008-15,6$ of GDP. In such case there are no steps made for increasing income of states pension system, except incising pension tax for recruiters and few affords to make business people - natural persons to pay minimal pension tax. In 2009 balance of expenses of pension system of Ukraine and GDP capacity reached the scale of $18 \%$ in $2010-17.7 \%$ Even after pension system reform in 2011 expenses on pension provision stay high in comparison with GDP: 2011 - 16\%, 2012 16.6\% 2013 17,3\%, 2014 - 16\% (Pension fund of Ukraine, 2015).

Analyzing all expenses on pension coverage, we must admit, that with every new year we pay more budget and 
GDP accumulated money on social needs of the state. Expenses on pension coverage are overstepping economic growth rate in the state that is caused with the big number of pensioners and decreasing number of tax payers, employed people, and imperfect system of money accumulation and financial crisis is a signal for negative tendencies to appear and develop in the nearest future (Svechnicki, Tkachenko, Chapko, 2010).

Increasing of expanses on the pension coverage is clearly seen through with the help of financial showings analysis of budget of Pension Fund of Ukraine for some years.

Pension fund of Ukraine is a central executive body that is in charge of states solidary system of obligatory pension insurance, that fundraises and accumulates all insurance payments, gives pensions and gets the documents ready for payoffs, provides in and on time payments and their funding

Income generation of pension fund of Ukraine is accounted for own incomings (insurance contributions for compulsory pension insurance of the country), money from Unemployment Fund and occupational injury and disease insurance fund and state budget of Ukraine.

Pension fund budget revenues of Ukraine (in consideration of money left at the beginning of the year) reached: 2010 - 193672 mil. UAH, 2011-212109 mil. UAH, 2012-224027 mil. UAH, 2013-252755 mil. UAH, 2014-245246 mil. UAH.

Main part of revenues are citizens own incomings: 2010 - 139156.0 mil. UAH., 2011 139056. mil. UAH, 2012 - 157980.0 mil. UAH., 2013 - 166864.0 mil. UAH., 2014 - 163813.8 mil. UAH.

The peculiarity of the budget of the Pension fund of Ukraine is the fact that the big item of income is are money from budget and their amount is serious. As they made in 2010 - 64087 mil. UAH., 2011 - 58317,0 mil. UAH., 2012 - 64494.0 mil. UAH., 2013 - 83233.6 mil. UAH., 2014 - mil. UAH., ( Pesion fund of Ukraine).

Unfortunately, for the moment the process of achieving of balance Pension budget fund is slow and contradictory. At the period from 1991 budget of the Pension fund was deficit-free only from 2002 till 2004 and in 2007, 2008. In 2005 deficit of the budget was 16.3 mil. UAH., 2006 7.3 mil. UAH.,2009 -13.1 mil. UAH.,2009 - 13.1 mil. UAH., 201026.6 mil. UAH., 2011-17.8 mil. UAH., 2012 15,3 mil. UAH., 2013 - 21.8 mil. UAH., 2014- 14.7 mil. UAH.

One of reasons of this negative developments is a misbalance in relations between participants in pension system with the context of revenue and spending of the budget of the Pension Fund and that is the main reason (Ponomarenko, 2013).

\section{Shadow economy in Ukraine}

With the problem of shadow economy existence all of the world countries come in the contact with. According to the first source it's capacity is at the level that doesn ' $t$ make serious impact on economy and in other sources there is is an evidence of existence of reproduced system of shadow economic relations. to the second category, unfortunately, Ukraine refers to, capacity of shadow economy that according to different sources is fixed at the level of $20-50 \%$ of GDP.

Presence of the big capacity of shadow economy signalizes about big amount of short payments of Pension fund and it impacts negatively at the functioning of the pension system and prosperity of pensioners.

National Statistical Reporting Service during last years determines capacity of shadow economy at the average from $15 \%$ to $18 \%$ of GDP. We must admit that those data's differ from data's from other intelligence agencies and scientists.

According to calculations of Ministry of economic development and trade of Ukraine, capacity of shadow economy in Ukraine for last 5 years reaches from $28 \%$ to $39 \%$ of GDP. This shoving calls of with different methods that take into account difference between income and expenditures, cash dynamics in circulation in overall production and using of electricity for production and dynamics of prices for end product and production profitability (Bochiy, Povoroznik, 2014).

According to data from fiscal services in 2012 general amount of shadow sector of Ukrainian economy was at least 350 bln.UAH per year, herewith, $170 \mathrm{bln} / \mathrm{UAH}$ of backdoor salary, $100 \mathrm{bln} / \mathrm{UAH}$ - non-cash money transferred in cash or foreign currency account in foreign banks, 35 bln.UAH - unofficial payments, 45 bln/UAH permanent assets, material resources and shadow sector services. (Bochiy, Povoroznik, 2014) In 2013 there were about 250 bln.UAH of Ukrainian tax payers, $41 \%$ of state purchases and public organizations were held without tenders (Shapoval, \& Kiryan, 2015).

So far almost third part of employable people is getting income in the sector of unregistered employment. One of reasons of hiding wages, according to tax payers opinion, are high stakes of payments to the pension fund, that in that case excludes big income of their organization. Second reason of spreading of the shadow economy is tendency of employers to decrease amount of and to hide income from taxes. In particular at legal companies salary is not payed in time according with current plan of salary payments. Third reason of being in shade economy sector is depreciation of pension as a stimulus, because half of Ukrainian pensioners are on the breadline.

\section{Serious fiscal overloading of the economy}

Excessive pension insurance stressing on economy are narrowing down potentialities of payment base and sources of pension inpayments. The best part of natural and legal persons are not paying pension fee. In-depth and lengthy economical crisis of the financial base of pension system.

World most developed countries that are members of Organisation for Economic Co-operation and Development, OECD and differ with high level of human 
services have an average showing of salary fund stressing only $23.3 \%$ whereas Ukraine $-43.3 \%$. (Pishulina, 2013).

Today in Ukraine charges for employers on unified social tax range from $36.76 \%$ to $49.7 \%$. Minimal sum of UST as of 01.01.2014 - 422.65 UAH. maximum sum of UST in 2014 is $7184,98 \mathrm{UAH}$, that is from salary that is more than 20106 UAH.

Sum of UST in comparison with minimal salary is serious, level of salary, anyway, is low enough in comparison with European countries. All in all when citizen that gets minimal salary pays UST and receives in the end $795.35 \mathrm{UAH}$ and that sum is lover then the living wage.

And when we add to UT for employers allocation of UST from the salary of worker amount of which is $3.6 \%$ and income tax amount of which is $15 \%$ - we will get different numbers. When organization gets 100UAH on outpayments connected with salary payments - worker gets in the end only 59.5 UAH (Volchanski, 2011).

In 2014 number of taxes and other charges was higher then $40 \%$ of Ukrainian GDP. We are able to understand states aspiration to get as much money to budget as they can, Nevertheless taxes shouldn't be higher the level in which amount of incomings is going to decrease.

\section{Low level of pension of the most of pensioners}

Up to 01.01.2015 number of pensioners in Ukraine was 12147.2 thousands, middle amount of pension is 1581.54 UAH. minimal pension is the same as minimum wage and is equal to $494 \mathrm{UAH}$ ( $42.3 \$$ at the exchange rate of National Bank of Ukraine as of 09.09.2015). Particularity of pension system of Ukraine is a low level of pension coverage and serious amount of pensioners. Relative share of poor people in Ukraine are pensioners. According to World Bank standards serious amount of pensioners are under the bread line. Low-income poverty threshold is existence on $1.25 \$$ per day.

In 2015 number of poor people only increased and that is connected with difficult economic status and with the apparition of new group of poor people - frontiers man from Crimea and Donbass. Number of frontiers is close to 500 thousands and that is only according to official statistics in 2014. Unofficial number probably is much higher. (Pension fund of Ukraine).

Vast majority of income pensioners are spending on food, medicines and housing rent. Furthermore, if on the average spending on food and housing rent in households of unemployed pensioners are much lower than in other types of households but pensioners spend money on medicines more than everyone. This situation shows pricing misbalance and bleakness of medical services, (Libanova, 2012).

In this regard we are going to examine composition of food basket for disabled people upon which the sum of living wage is calculated and the sum of minimal pension.

In keeping with food basket composition, upon which the sum of living wage is calculated, Ukrainian should eat per day 270gr of bread, 5 gr of bread, $250 \mathrm{gr}$ of potatoes, $50 \mathrm{gr}$ of cucumbers and tomatoes, half of an egg, one and a half glasses of milk, 25 gr of sausage, 61 gr of sugar and 18 gr of butter, 6 gr of rice 11 gr of sour cream. Basis of the food basket are bread, potatoes and milk. Bacon, if we into account daily scale of $5 \mathrm{~g}$, is enlisted as dainty. Fried fish and herring only on holidays (200 grams per month), and meat two or three times a month. Cheese, juice, mineral water or even filtrated fresh water were not taken into account at all.

Minimal comfort kit is three times lover then the one that is recommended by the institute for scientific research nutrition of Ministry of Health of Ukraine.

We must admit that the size of living wage for unemployable people (pensioners) intended lover (cheaper) compositions and consumption criteria of food and wardrobe items. In the same time necessity for medical supplies and goods, that they must to buy for their own money was not taken into consideration (chronical illnesses drugs, glasses and so on), and also payments for health care or surgery operations) (Tkachenko, 2012).

In the view of hard financial status big amount of pensioners are continuing to work. According to official data from the Statistic Agency, 63.2\% of people at the age of 50-59 and $15.5 \%$ people at the age of $60-70$. But those are official data, serious number of pensioners work in informal sectors of economy.

Dissatisfaction of senior citizens in Ukraine is caused with low pensions and absence of privileges on medical services and growing charges on housing and utility services.

\section{Reforms of pension system in 2015}

Solidary system of pension coverage up to this day is in crisis condition and it is caused by growing number of pensioners, and decreasing number of tax payers, growth of expenses for financing of the pension system and that is going to drive to failure of pension system.

In way of stabilization and further improvement of current situation we need to take measures to decrease expenses on financing pension system and to increase number of tax incomes into the pension system and to make pensioners life better,

From the beginning of 2015 number of steps were made to reform the solidary system, that will decrease spending on the pension coverage: offsetting of the pension solidary system and reduction of pension rights, received in advance. We are referring to reduction of things to make order in mechanism of pension awards, pensionable service and unitizing of pensions for deputies, judges and procurators and clerks.

Since 02.03.2015 Verkhovna Rada of Ukraine passed the law «About introduction of alterations into some legislative acts of Ukraine concerning changes in pension coverage $\gg 14$ pension laws that specify that during working period clerks, deputies, procurators, judges pension are not payed until they retire, were modified. In same way one should not take into the consideration pension type 
and law according to which it was assigned. Modifications listed above are going to bear on 11 thousands of people that are working on special posts.

While working, other categories of pensioners, pension are payed in the sum of $85 \%$ of assigned pension. This rate bears on those pensioners whose salary is not higher than 1.5 times from the living wage for people who lost employability.

Also when the new Tax Code is entering into the force on 01.01 .2015 , a tax form private person is taken ( $15 \%$ of basis of assessment) and military tax ( 1.5 basis of assessment) from pension including their indexation, that was charged in accordance with the law or monthly monetary payments if their pension is not higher than three sizes of minimal pension (per month), set up on 1 January of fiscal year.

Since 01.06 .2015 a single principle of pension was instituted, essence of this novation is in transition of all types of pensions under the single Law, and canceling of special pensions, except pensions for military people. Pensions for state clerks, taxmen, customs officers, judges and procurators and other scientific workers (Pension fund of Ukraine).

Consumed efforts that were made to decrease expenses on pension coverage, including cancelling special pensions and increasing demands for term of service and age of retiring for some categories of people is a positive signal of pension system reform. Most complicated initiatives from the social view are tax on pension and limitations for working pensioners are valid till 31.12.2015. Depending on economy, acts mentioned above are going to be cancelled or prolonged.

Hereafter we suggest to deal with ways of reforming the pension system of Ukraine.

\section{Decrease in deficit of pension fund of Ukraine}

Decrease in deficit of pension fund of Ukraine is possible if we make next steps:

- To make pension insurance system free from unusual expenses : financing from national budget extra payments for living wages for minimal government pension at the level made for people that lost their employability (MackTaggart, Horyuk\&Sigerl, 2014).

- Assigned to Pension fund of Ukraine source of income, except insurance, that is not connected with fiscal pressure. For example increasing of other types of taxes: excise taxes and VAT. Thanks to absence of pressure on the fund employers will not be motivated to be in shadow economy. - Changes in proportion VAT redistribution, to increase share of salary in the end product and European level services (Pischulina, 2013).

\section{Shadow salary legalization}

One of main tusk of economic reforms in Ukraine should be legalization of shadow sector of economy and overcoming of corruption.

Main forces for legalization of shadow economy should be appointed on:
- Strengthening of governmental control and discipline

- Creation of additional legal workspaces and special programs for unemployed

- Strengthening of forex control and overcoming outflow of currency

- Following at macro level dynamics of tax coefficient (correlation of taxes and all social obligatory payments)

- Access for small and medium practices

- Penal duties for persons working not legal

- Creation of special service for straggle with illegal employment

- Expansion of system of cashless transfers that could have been main form of transfers (Shapoval and Kiryan, 2015)

\section{Existence of mechanism of payment of unified social tax}

As an alternative we can decrease on employers in the way of redistribution of unified social tax that is payed to Pension fund of Ukraine, between a worker and employer, until we get a proportion of 50/50, without a payroll.

Accurately calculated scenario simultaneous increasing of a workers deposit to $6 \%$ (sanded to pension system), and gradual increase of workers deposit ( $2 \%$ a year) until they get unified social tax o worker and employer at the number of $18.8 \% / 18.8 \%$. During process we can reach the deficitfree budget of the Pension fund of Ukraine from 2016 that is being kept until 2047 (MackTaggart, Horyuk\&Sigerl, 2014).

\section{Establishment of second and third level of pension coverage in Ukraine}

Establishment of obligatory accumulative pension insurance and development of non-state pension insurance in Ukraine, that make serious social and economic impact on state and people. Smart and well-minded investment in future pension deposits are going to make a serious push for economy. Getting of the cheap and a long investment resources to the real sector is able to provide a rapid and steady growth of the domestic high-tech production with high added value.

This automatically leads to the increase in the number of jobs, reducing unemployment and increasing salary. The consequence will be an increase in domestic demand, which, in turn, with the respective cash resources will lead to further expansion of production and so on. In addition, the introduction of the accumulative component will allow to receive a pension from several sources, are going to improve the financial position of future pensioners (Pishchulina, 2013; Petrun 2012).

\section{Conclusion}

The pension system of Ukraine, up to this date, is in a difficult situation due to demographic and financial problems, poor living standards of pensioners. To overcoming the crisis we need to reform the pension system, assigned to the budget of the Pension Fund of 
independent sources of income, release the budget from fifth wheel functions, legalization of wages and changes in the mechanism of paying a single social contribution, those are the steps that will increase revenues to the pension system and reduce its expenses. In addition, an important step is the introduction and development of compulsory and voluntary pension savings insurance,that will increase the living standards of pensioners in the future and contributes to the development of the economy and the country in general.

\section{References}

Bochij, A., Povoroznik, V. (2014). Shadow economy in Ukraine: causes and ways of overcoming International Centre for Policy Studies. Source icps.com.ua

Volchanskij, A. (2011, 23 of Fabruary). Heaven and hell of the pension system. Economic truth. Source http://www.epravda.com.ua

State Statistics Committee of Ukraine (2015). Statistical information. Source 5 of September, 2015, http:// www.ukrstat.gov.ua

Kolesnikova, K. (2014). Save and multiply. Bulletin of the Pension Fund of Ukraine. 7, p. 28-31.

Libanova, E. M. (2006). A comprehensive demographic forecast of Ukraine for the period up to 2050 Moscow city. Ukrainian Center for Social Reforms.

Libanova, E. (2012). A well minded balance of generation is needed. Bulletin of the Pension Fund of Ukraine. 11, p. 24-27

McTaggart, G., Horruc, H. \& Sigerl, Ch. (2014). Recommendations for further reform of the pension system in Ukraine with the aim of its financial stability. Source December, 2014, http:/ finrep.kiev.ua/

Melnichenko, A. A. (2011). Problems and prospects of improving pension provision coverage of Ukrainian people. Actual problems of governance. 1, p. 134-142. Source http://www.kbuapa.kharkov.ua

Pension Fund of Ukraine (2015). Pension fund datas. Source 5 September 2015, http://www.pfu.gov.ua/

Petrun, A. (2012). Young investment. Bulletin of the Pension Fund of Ukraine. 7, p. 17-19.

Pischulina, S. (2013). According to the principle of personal responsibility. Bulletin of the Pension Fund of Ukraine. 2, p. 30-32.

Ponomarenko, I. V. (2013). Investigation of the effect of population aging on the size and structure of the economically active population in Ukraine and Europe. Effective economy. 2. Source http:// www.economy.nayka.com.ua

Svenchicki, M., Tkachenko, L. \& Chapko, I. (2010). Demographic and financial conditions of the pension reform in Ukraine: Forecast - 2050 Moscow. Analytical Consulting Center Blue Ribbon.

Tkachenko, L. (2012). The consumer basket for the pensioner. Bulletin of the Pension Fund of Ukraine. 4, p. 14-15. Shapoval M., \& Kirjan T. (2015). The main factors that slow down reforms in Ukraine. Bulletin of the Pension Fund of Ukraine. 4, p. 16-21.

Shevchuk, P. I. (2013). Problems of balancing budget of the Pension Fund of Ukraine. University research notes. 2, p. 315-321. source http://nbuv.gov.ua/j-pdf/Unzap_2013_2_50.pdf

\section{Александра СТАРОСТА}

\section{АНАЛИЗ СОЛИДАРНОЙ ПЕНСИОННОЙ СИСТЕМЫ УКРАИНЫ: ПРОБЛЕМЫ И ОСНОВНЫЕ НАПРАВЛЕНИЯ РЕФОРМИРОВАНИЯ}

Аннотация. Целью работы является анализ пенсионной системы Украины, определение ее основных проблемных направлений, определение необходимых шагов дальнейшего реформирования системы с учетом проводимых реформ в текущем периоде. Методика. Исследование осуществлено на основе статистических показателей, анализа демографических показателей, уровня теневой экономики, фискальной нагрузки в стране. Рассмотрены показатели бюджет Пенсионного фонда Украины, а также уровень доходов и расходов пенсионеров. Практическое значение. Поскольку количество пенсионеров растет, а количество плательщиков уменьшается соответствующая уменьшается сумма аккумулированных средств для пенсионных выплат, ведет к краху пенсионной системы или невыполнения ею основной функции - защиты нетрудоспособных слоев населения, поэтому необходимо осуществить дальнейшее реформирование системы с целью уменьшения дефицита, улучшение уровня жизни пенсионеров, внедрения и развития обязательного и добровольного пенсионного страхования. Значение/оригинальность. Указанные направления реформирования пенсионной системы позволяют улучшить функционирование пенсионной системы, улучшить финансовое положение сегодняшних и будущих пенсионеров, введение же накопительной составляющей способствует развитию экономики и страны в целом. 